\title{
STATUS AND EFFECTS OF FOOD PROVISIONING ON ECOLOGY OF ASSAMESE MONKEY (MACACA ASSAMENSIS) IN RAMDI AREA OF PALPA, NEPAL
}

\section{Krishna Adhikari, Laxman Khanal and \\ Mukesh Kumar Chalise}

Journal of Institute of Science and Technology

Volume 22, Issue 2, January 2018

ISSN: 2469-9062 (print), 2467-9240 (e)

\section{Editors:}

Prof. Dr. Kumar Sapkota

Prof. Dr. Armila Rajbhandari

Assoc. Prof. Dr. Gopi Chandra Kaphle

Mrs. Reshma Tuladhar

JIST, 22 (2): 183-190 (2018)

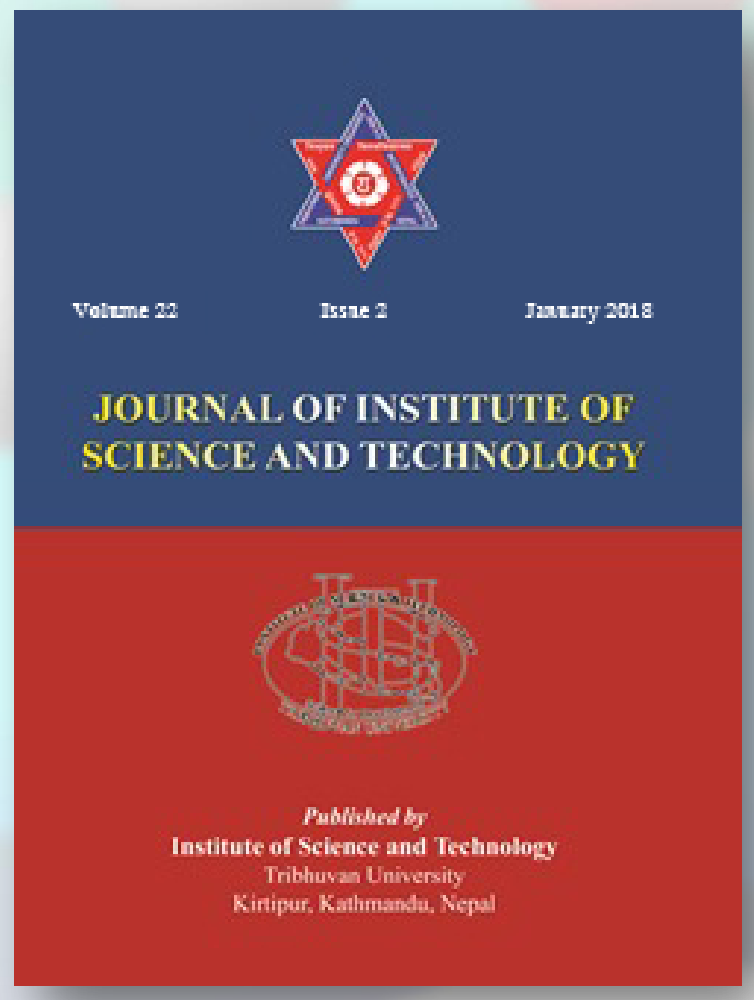

Published by:

Institute of Science and Technology

Tribhuvan University

Kirtipur, Kathmandu, Nepal 


\title{
STATUS AND EFFECTS OF FOOD PROVISIONING ON ECOLOGY OF ASSAMESE MONKEY (MACACA ASSAMENSIS) IN RAMDI AREA OF PALPA, NEPAL
}

\author{
Krishna Adhikari ${ }^{1}$, Laxman Khanal ${ }^{1,2}$ and Mukesh Kumar Chalise ${ }^{\mathbf{1 *}^{*}}$ \\ ${ }^{1}$ Central Department of Zoology, Tribhuvan University, Kirtipur, Kathmandu, Nepal \\ ${ }^{2}$ Kunming Institute of Zoology, University of Chinese Academy of Sciences, Yunnan 650223, China \\ *Corresponding E-mail: mukesh7@hotmail.com
}

Received: 3 October, 2017; Revised: 10 November, 2017; Accepted: 11 November, 2017

\begin{abstract}
The population status of Assamese monkey (Macaca assamensis) (McClelland 1840) and its interaction with the local people is poorly documented in Nepal. In 2014, we studied the population status, diurnal time budget and human-monkey conflict in Ramdi, Nepal by direct count, scan sampling and questionnaire survey methods, respectively. Two troops of Assamese monkey having total population of 48 with the mean troop size of 24 individuals were recorded in the study area. The group density was 0.33 groups $/ \mathrm{km}^{2}$ with a population density of 6 individuals/ $\mathrm{km}^{2}$. The male to female adult sex ratio was 1:1.75 and the infant to female ratio was 0.85 . The provisioned troop of Assamese monkey in Ramdi spent less time in feeding and movement while higher time was invested in resting and grooming than the nonspecific populations in the wild habitats. The human-monkey conflict is high in Ramdi, primarily due to the crop-raiding from fields and even the storage; the major crops raided are maize, vegetables, pulses and fruits. The higher reproductive success in terms of infant to adult female ratio, increased human-monkey conflicts and lesser investment of the diurnal time in foraging and feeding by Assamese monkey troop of Ramdi might be associated with the food provisioning.
\end{abstract}

Keywords: Assamese monkey (Macaca assamensis), Ramdi, Behavior, Conflict, Group density.

\section{INTRODUCTION}

Among the non-human primates, three species of monkeys have been reported from Nepal; Rhesus monkey (Macaca mulatta), Assamese monkey (Macaca assamensis), and Hanuman Langur (Semnopithecus entellus). Macaques/monkeys (genus Macaca; Primates: Cercopithecidae) are an ecologically extremely adaptive primate taxon that is distributed more widely than any other nonhuman primate genus (Schulke et al., 2011). Assamese monkey is one of the less common primate species and is distributed patchily in Nepal (Chalise, 2013). The 'Nepal population' of Assam macaque differs in pelage color, morphometric indices and distribution range with their nearest conspecific populations (M. assamensis pelops) from adjacent countries like India and Bhutan; hence they have been doubted for the distinct subspecies status and considered as " $M$. assamensis Nepal Population" and warranted the need of taxonomic revision (Chalise, 2005 \& 2013; Molur et al., 2003). Categorized as 'Near Threatened' by IUCN (Boonratana et al., 2008), its Nepal population is one of the least studied primates that has been nationally listed 'Endangered' and protected by the National Park and Wildlife Protection Act-1973 of Nepal (Chalise, 2013; Chalise et al., 2013).

The Assamese monkey is reported from mid-hills and high Montana forest, but their ecological and behavioral details are poorly known (Chalise et al. 2013). It is locally known as Pahare Bandar or Kalo Banar or Kala-Ganda (Chalise, 2010). It resembles to the rhesus monkey except having a brownish-grey to yellowish-grey coat, which is uniform in pelage, lacks a pinkish face and absence of red buttocks (Chalise, 2008); and heavier and larger than rhesus weighing more than $12 \mathrm{~kg}$ (Chalise, 2003). It has darker fur in exposed area while whitish blonde-haired to ashy white in abdominal and inner parts (Chalise et al., 
2005). Generally, adult Assamese monkey is of nearly 2 feet in head and body length while tail is one-third of it.

The estimated total population of Assamese monkey in Nepal is 1,099 individuals in 51 troops in different habitat of mid-hills of Nepal (Chalise, 2013). They are diurnal animals found along the hills, valleys and upland river basin along the eastwest mountainous range with diversified ecological zones (Wada, 2005). They are found in riverside hill-Sal forest area to mixed deciduous and evergreen forest of Schima-Castanopsis, Elaeocarpus-Macaranga forests in mid-hills and Quercus-Pinus-Rhododendron forests of lower Himalaya. They are arboreal, terrestrial and omnivorous animals which are seen doing their social and other activities in the ground with sluggish movement (Chalise et al., 2005). Assamese monkeys live in multi-male and multifemale social troops, and they mate promiscuously with males disperse, whereas females are philopatric (Thierry, 2007).

Some studies have been conducted on population, distribution, behaviour and conservation of Assamese monkey at different forest fragments (Chalise, 2013). Due to the narrow habitat range, Assamese monkeys are facing strong negative impacts on their survival and the population is decreasing in many parts. Anthropogenic activities like deforestation, agricultural expansion, development projects of roads and hydroelectric power generation are reported as the major threats to this species (Chalise, 2013; Molur et al., 2003). In many parts of Nepal, it has been observed as one of the major crop raiders and in some areas even retaliatory killings have been reported (Chalise, 2010). In this context, the extensive study about Assamese monkey is needed to establish baseline information for many parts of the country. The catchment areas of Kaligandaki River in Mid Hills have been described as one of the major potential habitat area for Assamese monkey (Paudel \& Chalise, 2017). The Ramdi Area of Palpa and Syangja district is the transient zone between the tropical and sub-tropical climatic conditions and could provide the suitable habitats for this species. Therefore, this research aimed to explore the existing population of Assamese monkey in Ramdi area, document the general behaviour in semiprovisioned conditions and account the level of conflicts with human. The findings of this study might be valuable in conservation and management of such endangered primate in Nepal.

\section{MATERIALS AND METHODS}

\section{Study Area}

Ramdi area is in Darlamdada and Khanichhap VDCs of Palpa district and Malunga VDC of Syangja district. Palpa district has elevation range from $200 \mathrm{~m}$ to $2000 \mathrm{~m}$ above sea level (asl) and spans between $27^{\circ} 40^{\prime} \mathrm{N}$ to $27^{\circ} 57^{\prime} \mathrm{N}$ and $83^{\circ} 14^{\prime} \mathrm{E}$ to $84^{\circ}$ 02'E (DDO Palpa 2013) while Syangja district has the elevation range from $366 \mathrm{~m}$ to 2512 $\mathrm{m}$ asl spanning between $27^{\circ} 52^{\prime}$ to $28^{\circ} 13^{\prime}$ North and longitude $83^{\circ} 27^{\prime}$ to $83^{\circ} 46^{\prime}$ east (DDO Syangja, 2013).

The holy place Ramdi on the bank of Kaligandaki River lies is in Darlamdanda between $27^{\circ} 55^{\prime} \mathrm{N}$, $83^{\circ} 37^{\prime} \mathrm{E} / 27.91^{\circ} \mathrm{N}, 83.61^{\circ} \mathrm{E}$. Ramdi is typical Mahabarata hill, mostly sub-tropical type of climate but partly temperate climate with rainy summer and dry winter. The southern side is sunny and much drier than northern forest side (DDO Palpa, 2013). The mean monthly minimum temperature of the area is $15.45^{\circ} \mathrm{C}$ and the mean monthly maximum temperature is $26.4^{\circ} \mathrm{C}$. December, January and February are the coldest months while April, May and June are the hottest months (Source: Department of Hydrology and Meteorology, 2015).

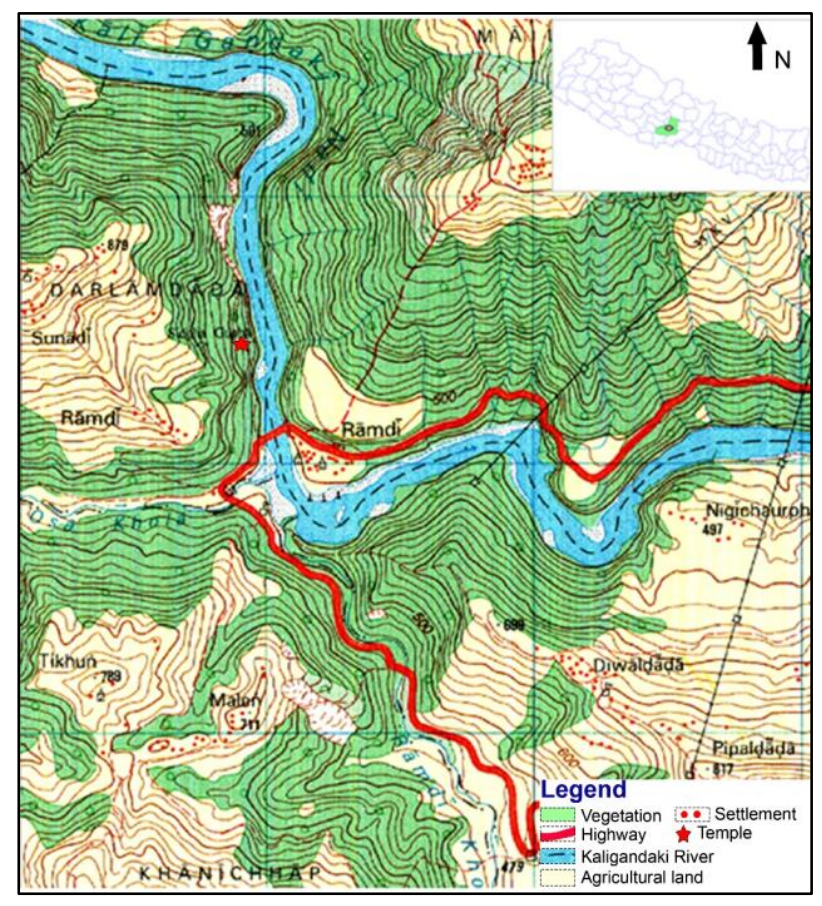

Fig. 1. Topographic map of Ramdi Area (Source: Survey Department of Nepal, 1995).

Some of the common floras of this area are Sal (Shorearobusta), Chilaune (Schimawallichii), 
Bhalayo (Semecarpus anacardium), Bel (Aegle marmelos), Fandir/Jamun (Syzygium cumini), Pipal (Ficus religiosa), Angeri (Berchemiaedgeworthi), Bar (Ficusbengalensis), Khanyu (Ficus semicordata), Khirro (Sapium insigne), Simal (Bombas ceiba), etc. The major mammalian fauna of the area includes Rhesus monkey (Macaca mulatta), Hanuman langur (Semnopithecus entellus), Common leopard (Panthera pardus), Barking deer (Muntiacusmuntjak), Yellow throated martin (Martes flavigula), Jackal (Canis aurens), Jungle cat (Felis chaus), Porcupine (Hystrix indica), Forest rat (Bandicotasp.), Fox (Vulpesvulpes), Hares (Lepus sp.), Mouse (Mus musculus) etc. (DDO Palpa, 2013).

\section{METHODS}

\section{Population Count}

Population count of Assamese monkey in Ramdi area was carried out in 2014 from accessible roads and walking trails. Before the detail population census, the troops were recognized through continuous observation of individuals with their specific identifying characters like body size; special marking on the body, coloration and behaviors etc. and the population census was done by direct counting method. Troop composition was separated by direct counting the individuals in each group and age and sex were distinguished by their body color, body proportion, height and body size as explained by Roonwal and Mohnot (1977).

\section{Behavioral Observations}

In order to assess the behavioral differences of semi-provisioned troop of Assamese monkey at Siddha Baba Temple area with that of wild troops described in previous studies, behavioral samplings were done by using the scan sampling method (Altman, 1974) and continuous average group scanning (Chalise, 2000, 2003 \& 2005). Behaviors like foraging, feeding, resting, moving and grooming were recorded during scanning period of data collection. Assamese monkey troops were observed for 10 hours (from 07:00 to 17.00) every day in the months of January, February, March of 2014 and 12 hours (from 06.00 to 18.00) every day in the months of August, September, October in 2014 with the behavioral sampling for total 378 hours.

\section{Human-Monkey Conflict}

A total of 100 respondents were randomly selected from the people living around the Ramdi area for this study. Semi-structured questionnaires were used to get the information on human-monkey conflicts. The respondents were interviewed separately to ensure the independence of the individual response. The questionnaires were designed to obtain the people's perception on Assamese monkey population change in Ramdi and different aspects of crop raiding by the monkeys (frequency, time of the day, types of the crop damaged, amount of annual loss due to crop raid and methods adopted to prevent the crop raid).

\section{Data Analysis}

The collected data was analyzed with the use of MS EXCEL 2007. The infant to female ratio of the monkey was calculated by dividing total number of infants by total number of adult females similarly sex ratio was calculated by dividing total number of adult male by total number of adult female (Chalise, 2003). The statistical significance of the difference in agesex composition between the two troops was tested by paired t-test assessing its significance at the threshold of 0.05 . The behavioral data for two seasons of the year were combined and analyzed. The data from behavioral sampling and questionnaire survey were analyzed by descriptive statistics (percentages, frequencies) and charts and table were used to present the data in most simplified and understandable form.

\section{RESULTS}

\section{Population}

Population surveys throughout the study area $(\sim 8$ $\mathrm{km}^{2}$ ) were carried out from all the accessible trails. A total of 48 individuals from two different troops of Assamese monkey were counted. Palpa troop-A consisted higher number of individuals $(n=27)$, than that of Syangja troop-B $(n=21)$. The average troop size was of 24 individuals. There were $12.5 \%$ infants, $27.08 \%$ juvenile, $37.5 \%$ sub adult, $8.33 \%$ adult male and $14.58 \%$ adult females. There was no significant difference in age-sex composition between the troop-A and troop- $\mathrm{B}$ ( $\mathrm{t}$-value $=1.07, \mathrm{df}=7, \mathrm{P}=0.304$ ). The adult sex ratio (male: female) from age sex group separated troops was $1: 1.75$, and infant to female ratio was found 0.85:1.00 (85 infants per 100 adult females) during the study period. The overall group density was 0.33 groups $/ \mathrm{km}^{2}$ with a population density of 6 individuals/ $\mathrm{km}^{2}$. 
Table 1: Population of Assamese monkey in Ramdi area.

\begin{tabular}{|l|c|c|c|}
\hline \multicolumn{1}{|c|}{ Categories } & Palpa Troop 'A' & Syangja Troop 'B' & Total Population \\
\hline Adult Male & 2 & 2 & 4 \\
\hline Adult Female & 4 & 3 & 7 \\
\hline Sub adult Male & 4 & 3 & 7 \\
\hline Sub adult Female & 6 & 5 & 11 \\
\hline Juvenile Male & 4 & 2 & 6 \\
\hline Juvenile Female & 4 & 1 & 2 \\
\hline Infant Male & 1 & 2 & 48 \\
\hline Infant Female & 2 & 21 & \\
\hline Total & 27 & & \\
\hline Average troop size & 24 individuals per troop & \\
\hline Sex ratio & male: female $=1: 1.75$ & \\
\hline Infant to adult female ratio & 0.85 infant per adult female \\
\hline
\end{tabular}

\section{Behavior}

The Palpa troop 'A' $(n=27)$ of Siddha Baba temple area, Ramdi was selected as focal troop for studying behavior. Out of the 378 hours of time spent in the jungle, the focal troop was connected for 318 hours and 7 minutes to study the diurnal activity pattern and time budget. Among the five types of behavior (feeding, moving, resting, foraging and grooming) studied, maximum time (117 hours 36 minutes, 36.96\%) was invested in feeding behavior which was followed by resting (96 hours 13 minutes, 30.24\%), social behavior (76 hours 19 minutes, $23.99 \%$ ), foraging (13 hours 10 minutes, $4.14 \%)$ and movement(14 hours 49 minutes, $4.65 \%$ ).

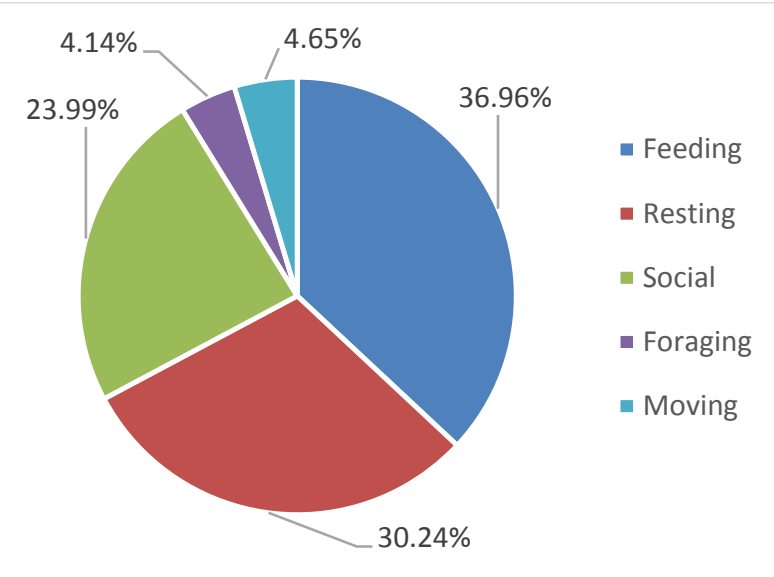

Fig. 2. Diurnal activity budget of Assamese monkey in Ramdi area.

\section{Human-Monkey conflict}

All of the respondents i.e. $100 \%(\mathrm{~N}=100)$ considered monkey as the nuisance. Majority of respondents $(66 \%)$ who were directly involved in agriculture reported crop raiding as the major problem. Crops mostly raided by monkeys included maize (35\%), vegetables (20\%), pulses (13\%), fruits $(13 \%)$, potato $(6 \%)$, and rice $(2 \%)$.

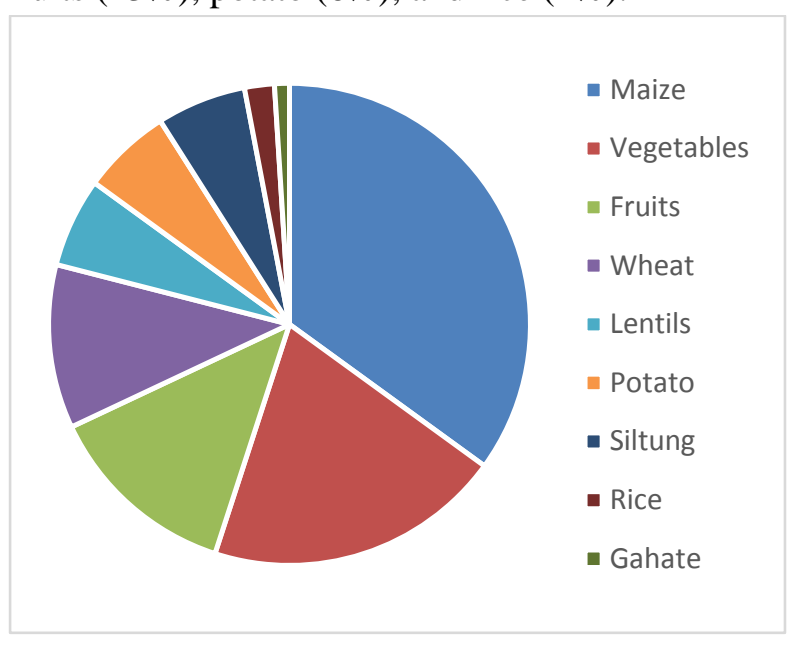

\section{Fig. 3. Respondents' view on percentage of crop damage by monkey in Ramdi Area.}

Food scarcity, as reported by $78 \%$ respondents was the major cause for increasing human-monkey conflicts in the Ramdi area. Only 19\% (N=100) of the total respondents said they have given food for monkey while $37 \%(\mathrm{~N}=100)$ reported they had seen the artificial provisioning by other people. In 
an average 35 pilgrims/visitors at the Siddha Baba temple provided food to the monkey at the rate of approximately 200 grams per person per day that accounted about 259 grams of supplement food per monkey per day. The provisioned food included rice, wheat, maize, gram, peanut, banana, orange, apple etc. According to 59\% respondents, monkeys are mostly active in morning time i.e. 5 AM-11AM and they create problems to local residents. Stone throw-catapult was reported by the $97 \%$ respondents and was also observed to be the most effective method to ward off monkeys. Other methods like scolding and charging, screening of the house, stick charging etc. are also used to ward off monkeys.

\section{DISCUSSION \\ Population}

This study explored the population status of Assamese monkey in Ramdi area of Palpa and Syangja districts and the diurnal behavior of semiprovisioned troop inhabiting around Siddha Baba temple was observed. Two troops of Assamese monkey with the mean troop size of 24 individuals (range 21-27) were found inhabiting the Ramdi area, one troop on the eastern side and another on the western side of the Kaligandaki River. The average troop size of Assamese monkey in Ramdi area is higher than other studies in Nepal, for examples- Wada (2005) reported it 19.1 with the range of five to 34 from the survey along multiple rivers in Nepal, while Chalise (2013) reported it to be of 21.55 with the range of one to 35 from different forest fragments and Chalise et al. (2013) reported the average troop size of 23.71 in Shivapuri Nagarjun National Park. The group density of this study was 0.33 groups $/ \mathrm{km}^{2}$ with a population density of 6 individuals $/ \mathrm{km}^{2}$. There is less adult male population than adult female (sex ratio $1: 1.75$ ) and the ratio is more near to that of Assamese monkey (1:1.6) in Makalu Barun National Park (MBNP) (Chalise, 2003). In Ramdi, there were $12.5 \%$ infants, $27.08 \%$ juvenile, $37.5 \%$ young, $8.33 \%$ adult male and $14.58 \%$ adult females. Unlike this ratio, Chalise et al. (2013) reported $56.9 \%$ adults and $43.1 \%$ immature. The population composition of Assamese monkey in Ramdi is different from other studies because they are probably the only groups in Nepal which live in religious place and are habituated with people where they find waste food easily.

The infants to adult female ratio was 0.85 in Ramdi during this study, which is more than Chalise et al.
(2013); according to them each adult female had 0.67 infants in Shivapuri Nagarjun National Park. Female reproductive performance is often limited by foraging conditions as food provides the energy needed to maintain regular reproductive cycles and reduce the costs of reproduction (Harcourt, 1989). Abundance of high-quality food sources has been observed to lead to shortening of the weaning process facilitating subsequent conception (Lee, 1987). Borries et al. (2001) also explained the provisioned primate groups to have higher birth rates, shorter lactation periods and shorter interbirth intervals compared to un-provisioned groups. Higher infant to female ratio or the birth ratio in the Ramdi troops of Assamese monkey may be the consequence of partial food provisioning.

\section{Behavior}

The semi-provisioned Assamese monkey of Siddha Baba temple area spent $36.96 \%$ of time in feeding and only $4.14 \%$ in foraging activities; while they spent $30.24 \%$ diurnal time in resting and $23.99 \%$ in social behavior like grooming. In the wild, Assamese monkey spend greater percentage of time in foraging and feeding activities; for example$43.4 \%$ in LNP (Chalise, 2010), 44\% in MBCA (Chalise, 2003), 47\% along Kaligandaki river bank (Paudel \& Chalise, 2017), which is higher than this study i.e. $36.96 \%$. Chalise et al. (2013) studied a habituated Assamese monkey troop in Shivapuri Nagarjun National Park and found $46 \%$ of the diurnal time invested in foraging/eating, $19 \%$ in resting, $16 \%$ in locomotion, $12 \%$ in sleeping, $6 \%$ in grooming and $1 \%$ in playing. On the other hand, the Assamese monkeys of Ramdi spent $30.24 \%$ of time in resting followed by $23.99 \%$ in social and $4.14 \%$ in foraging and $4.65 \%$ in moving in this study which differs markedly from the previous studies of monkey in Nepal (Chalise, 2003 \& 2010). Chalise (2010) had recorded $18.5 \%$ in resting, $31.7 \%$ in moving and $3.4 \%$ of time in grooming behavior in LNP, similarly, Chalise (2003) had recorded 18\% in resting, $25 \%$ in moving and $13 \%$ in grooming in MBNP. In contrast to this, Zhou et al. (2007) reported an average of $39.6 \%$ of time spent in resting, $33.2 \%$ in moving, $18.3 \%$ feeding, $7.5 \%$ in social behavior and $1.4 \%$ in other behaviors. They further reported the significant seasonal variations in time investment with the increase in time investment on feeding during dry season than in rainy season. It is obvious that in natural habitat they should invest much more time to acquire food than to spend in other social activities (Chalise et al., 2005). In Ramdi, the troop of Assam monkeys 
in temple area get food from the Hindu pilgrims, in addition they also raid the crops from the fields and storage of local people. Because of getting the human food with higher concentration of nutrients, they invest less time in foraging, feeding and movement while they have the spare time to invest on resting and grooming.

\section{Human-Monkey Conflict}

In many parts of the distribution range, anthropogenic habitat alteration has forced the nonhuman primates into conflict interactions with humans and their livelihood activities, especially through crop raiding (Priston et al., 2012). Crop damage caused by raiding primates is one of the most widespread and common examples of humanprimate conflicts in the areas where local people are mainly subsistence farmers (Hill, 1998). When the supply of natural food is not enough, high quality and easily digested human food is a good alternative form of nutrition for primates, which could be the most important cause of the intensity of crop raiding (Khatun et al. 2013). In Ramdi area, 66\% respondents $(\mathrm{N}=100)$ highlighted crop raiding as the major problem caused by Assamese monkeys while grabbing/taking of food materials and clothes was reported by $47 \%$ respondents. Almost similar to our study, Mc. Court (2005) reported 92\% respondents of Hetauda found suffered from crop damage by rhesus monkeys. Among different crops, damage of maze (35\%) was found to be the highest followed by vegetables (20\%) which is almost consistent with the results of Chalise (2001, 2003). Chalise and Johnson (2001) reported that crop depredation proportion by monkeys varied with crops. In MBCA, they recorded highest loss of maize (32\%) followed by potato (24\%), rice (14\%), fruits $(12 \%)$, millets $(11 \%)$, wheat $(4 \%)$, buckwheat $(2 \%)$ and pulses (1\%). Crop raiding is an essential component of the ecology of primates inhabiting human settlements (Naughton-Treves et al., 1998) but it is likely to minimize the tolerance of subsistence farmers towards conservation of such crop-raider threatened primate species (Khatun et al., 2013). This fact may be useful in predicting the vulnerability of the Assamese monkey survival in Ramdi area. Artificial provisioning causes changes in the diet, home range and habitat and even the behavior of the monkey (Southwick et al., 1976). In Ramdi area monkey are habituated to human because of provisioning of foods, therefore their diet, home range, habitat and behavior are also changed. Most of the respondents believe the scarcity of food, increase in monkey population, loss of habitat, behavioral changes of monkeys due to artificial provisioning by Hindu pilgrims etc. as the major causes of monkeys turning into crop-raiders. Monkeys living in the habitat with fewer wild food resources are more likely to utilize human settlements and areas around them with dependence on crop foods (Yamada \& Muroyama, 2010). The food provided by the Hindu pilgrims in temple areas of Ramdi might have caused behavioral changes and increased their dependence to provisioned food rather than foraging from the wild. The food supplied in the temples (about 259 grams per monkey) may be not be enough and to meet the nutrients requirement the monkeys enter the crop fields, orchards or even the grain storage houses instead of foraging the wild food, which increase the conflicts with local people. The detail assessment of the habitat quality and its management would minimize the human-monkey conflicts and it will be helpful in conservation of the endangered and protected Assamese monkey in Ramdi.

\section{CONCLUSION}

Ramdi area was found inhabited by two troops of Assamese monkeys with the mean troop size of 24 (Range 21-27), the group density of 0.33 groups / $\mathrm{km}^{2}$ and a population density of 6 individuals/ $\mathrm{km}^{2}$. There was less adult male population than adult female (sex ratio 1:1.75). Monkeys of Ramdi spent less time in feeding, foraging and movement but invested higher time in resting and social behaviors when compared with the wild troops. Humanmonkey conflict in Ramdi was found to be a serious social problem which may be due to the proximity of the forest to the settlement, artificial provisioning in the nearby temples, availability of palatable crops, abundance of safe hiding sites on the rocky outcrops on the bank of Kaligandaki River. We conclude that the food provisioning to the Assamese monkeys in Ramdi area has changed the general behavior and reproductive success, and raised the human-monkey conflicts.

\section{ACKNOWLEDGEMENT}

We express sincere thanks to Prof. Dr. Ranjana Gupta, Head of Central Department of Zoology for her kind support in carrying out this work. We are thankful to Mr. Kul Bahadur Thapa and the local people of Ramdi Area for their support in the field works. The respondents of the questionnaire survey are acknowledged for providing the valuable information. 


\section{REFERENCES}

Altman, J. (1974). Observational study of Behavior: Sampling Methods. Behavior, 49: 227-267.

Boonratana, R.; Chalise, M. K.; Das, J.; Htun, S. and Timmins, R. J. (2008). Macaca assamensis. In: The IUCN Red List of Threatened Species. e.T12549A3354977.

Borries, C.; Koenig, A.; Winkler, P. (2001). Variation of life history traits and mating patterns in female langur monkeys (Semnopithecus entellus). Behavioral Ecology and Sociobiology, 50: 391-402.

Chalise, M. K. (1999). Some behavioral and ecological Aspects of Assamese Monkeys (Macaca assamensis) in Makalu-Barun Area, Nepal. Nepal Journal of Science and Technology, 1: 85-90. 38.

Chalise, M. K. (2000). Biodiversity of wild food plants in relation to the monkeys feeding ecology. Proceeding of Eighth International Workshop of BIO-REFOR, Japan, under Biotechnology Applications for Reforestation and Bio-divesrsity Conservation: 289-294.

Chalise, M. K. (2003). Assamese Macaques (Macaca assamensis) in Nepal. Primate Conservation, 19: 99-107.

Chalise, M. K. (2005). New Characters of Assamese Monkeys in Nepal. (Abs) National Conference on Animal Taxonomy Emerging Trends Department of Zoology, Sacred Heart College, Thevara, Kochi682013 Kerela, India. January, 14-15: 25.

Chalise, M. K. (2008). Primate census in Kathmandu and west parts of Nepal. Journal of Natural History Museum, 23: 60-64.

Chalise, M. K. (2010). A study of Assamese monkey in Sebrusbeshi of Langtang National park, Nepal. Journal of Natural History Museum, 25: 54-61.

Chalise, M. K. (2013). Fragmented Primate Population of Nepal. In: Primates in Fragments: Complexity and Resilience, Development in Primatology, Progress and Prospects, Marsh, L.K. and Chapman, C. A. (eds.). Springer Science + Business Media, New York. pp. 329-356.

Chalise, M. K.; Bhattarai, G. P. and Pandey, B. (2013). Ecology and Behavior of Assamese monkey in Shivapuri Nagarjun National Park, Nepal. Journal of Natural History Museum, 27:12-24.
Chalise, M. K. and Johnson, R. (2001). A preliminary report on farmer attitudes toward crop-raiding monkeys in Nepal. American Journal of Primatology, 54 (1): 138-155.

Chalise, M. K.; Karki, J. B. and Ghimire, M. K. (2005). Status in Nepal: Non-human Primate. Special issue published on the occasion of 10th Wildlife Week, 2005. Department of National Parks and Wildlife Conservation, Government of Nepal. pp. 19-26.

DDO, Palpa (2013). District Profile, Statistics Office, District Development Committee, Palpa.

DDO, Syangja (2013). District Profile, Statistics Office, District Development Committee, Syangja.

Harcourt, A. H. (1989). Environment, competition and reproductive performance of female monkeys. Trends in Ecology and Evolution, 4:101-105

Hill, C. M. (1998). Conflicting attitudes towards elephants around the Budongo Forest Reserce, Uganda. Environmental Conservation, 26: 218-228.

Khatun, U. H.; Ahsan, M. F. and Roskaft, E. (2013). Local People's Perceptions of Crop Damage by Common Langurs (Semnopithecus entellus) and Human-langur Conflict in Keshabpur of Bangladesh. Environment and Natural Resources Research, 3 (1). doi:10.5539/enrr.v3n1p111

Lee, P. C. (1987). Nutrition, fertility and maternal investment in primates. Journal of Zoology, 213: 409-422.

Mc-Court, P. (2005). Urban human-monkey conflict in the vicinity of the Institute of forestry, Hetauda, Nepal.

Molur, S.; Brandon-Jones, D.; Dittus, W.; Eudey, A.; Kumar, A.; Singh, M. et al. (2003). Status of South Asian Primates: Conservation Assessment and Management plan (CAMP) workshop report, viii+432 pp. 2002 March 5-9; Coimbatore, India. Tamil Nadu (India): Zoo outreach Org/Cons Breed Spec Group, South Asia.

Naughton-Treves, L.; Treves, A.; Chapman, C. and Wrangham, R. (1998). Temporal patterns of crop-raiding by primates: linking food availability in croplands and adjacent forest. Journal of Applied Ecology, 35(4): 596-606. http://dx.doi.org/10.1046/j.1365-2664.1998. 3540596.x 
Paudel, P. K. and Chalise, M. K. (2017). General behavior and vegetation associated with the Assamese monkey (Macaca assamensis) along Kaligandaki River bank, Western Nepal. Journal of Institute of Science and Technology, 22 (1): 110-119.

Priston, N. E.; Wyper, R. M. and Lee, P. C. (2012). Buton macaques (Macaca ochreata brunnescens): crops, conflict, and behavior on farms. American Journal of Primatology, 74 (1): 29-36. doi:10.1002/ajp.21003

Roonwal, M. L. and Mohnot, S. M. (1977). Primates of South Asia: Ecology, Sociobiology and Behaviour. Cambridge, Massachusetts, Harvard University Press.

Schülke, O.; Pesek, D.; Whitman, B. J. and Ostner, J. (2011). Ecology of Assamese macaques (Macaca assamensis) at PhuKhieo Wildlife Sanctuary, Thailand. Journal of Wildlife in Thailand, 18 (1).

Southwick, C. H.; Beg, M. A. and Siddiqui, M. R. (1976). A population survey of Rhesus monkeys in villages, towns and temples of northern India. Ecology, 42 (3): 538-547.

Thierry, B. (2007). The macaques: A doublelayered social organization. In Campbell, C.; Fuentes, A. and MacKinnon, K. (Eds.), Primates in perspective (pp. 224-239). Oxford: Oxford University Press.

Wada, K. (2005). The distribution pattern of rhesus and Assamese monkeys in Nepal. Primates, 46 (2): 115-119. doi:10.1007/s10329-0040112-x

Yamada, A. and Muroyama Y. (2010). Effects of vegetation type on habitat use by cropraiding Japanese macaques during a foodscarce season. Primates, 51 (2): 159-166. doi:10.1007/s10329-009-0183-9.

Zhou, Q. H.; Wei, H.; Huang, C. H.; Li, Y.; Lu, M. X. and Huang, C. M. (2007). Activity patterns and time budgets of the Assamese macaque Macaca assamensis in the Longgang Nature Reserve, China. Acta Zoologica Sinica, 53: 791-799. 